\title{
IMPLEMENTASI PENANAMAN NILAI PANCASILA PADA PESERTA DIDIK
}

\author{
Abdul Latief ${ }^{1 *}$, Ade Rahayu ${ }^{1}$ \\ Prodi PPKn, Universitas Al Asyariah Mandar \\ *Email: latief2002@gmail.com
}

\begin{abstract}
This study aims to see how to instill the value of Pancasila in students. The appropriate type of research is descriptive qualitative research. The research instrument used deep interview, observation and documentation.Research Subjects are Educators /Teachers. The focus of this research is the cultivation of the three principles of Pancasila by educators/teachers at SMA Negeri 1 Polewali, West Sulawesi Province. It was found that the implementation of the implanting of the three values of Pancasila in students was carried out by institutions/schools through the role of educators in the learning process in the classroom, through planting material, extracurricular activities, collaborative activities with local government partners, as well as community and parent participation.
\end{abstract}

Keywords: planting, the value of Pancasila

\section{PENDAHULUAN}

Pada bulan Juli tahun 2019 Kementerian Pendidikan dan Kebudayaan RI bekerja sama dengan Kementerian Koordinator Pembangunan Manusia dan Kebudayaan, Badan Pembinaan Ideologi Pancasila, dan Kementerian Agama berupaya menguatkan nilai dan moral Pancasila dengan cara mengeluarkan Naskah yang berjudul Penguatan Pembelajaran Nilai dan Moral Pancasila. Naskah dalam bentuk modul ini berisi tentang arah, tujuan, prosedur, dan indikator keberhasilan penguatan pembelajaran nilai dan moral Pancasila bagi sekolah tingkat SLB, Paud, Pendidikan Dasar (SD, SMP) dan Pendidikan Menengah (SMA, SMK). (Pusat Kurikulum dan Pembelajaran Kemdikbud, 2019).

Permasalahan yang dihadapi akhir-akhir ini yaitu mulai kurangnya pengetahuan mengenai nilai-nilai Pancasila. Terlihat dari mulai berkurangnya pengetahuan dan pengamalan pancasila pada masyarakat, mulai lunturnya rasa persatuan dan kesatuan bangsa dan berkurangnya sikap cinta tanah air dan terjadinya degradasi moral terhadap peserta didik. Peneliti berpendapat bahwa lembaga pendidikan sekolah pendidikan menengah memiliki peran sangat penting dalam penanaman nilai Pancasila kepada peserta didik. Termasuk pengamalannya 
dalam kehidupan sehari-hari. Aktifitas yang dilakukan peserta didik di sekolah juga akan berpengaruh pada perkembangan moral dan kepribadian peserta didik. Pendidikan dan penanaman nilai-nilai luhur bangsa yang terkandung dalam Pancasila sila ke 3 (tiga) sangat penting untuk diimplementasikan dan dibiasakan pada peserta didik. Dijelaskan dalam penelitian terdahulu bahwa nilai-nilai utama yang termuat dalam sila persatuan Indonesia meliputi nilai kesatuan, kebangsaan dan kepribadian. (Sri Soeprapto, 2017).Disarankan kepada pendidik sekolah menengah untuk menanamkan kepada peserta didik pemahaman mengenai nilai Pancasila, karena nantinya akan diaplikasikan oleh peserta didik dalam kehidupan sehari-hari. (Pratiwi, 2018)

Permasalahan yang akan diteliti dalam penelitian ini adalah bagaimana bentuk penanaman nilai pancasila (sila ketiga) yang dilakukan oleh pendidik sekolah tingkat menengah (SMA). Tujuan dari penelitian ini adalah untuk mengetahui bagaimana bentuk penanaman nilai Pancasila oleh pendidik kepada peserta didik.

Pada dasarnya peran pendidik beraneka ragam dan multiguna. Pendidik memiliki peran sebagai controller, organizer, assessor, prompter, participant, resource, tutor dan observer. Selanjutnya (Asmani A. J., 2011) menjelaskan lebih lanjut mengenai fungsi dan tugas guru antara lain; educator (pendidik), leader (pemimpin), fasilitator (pemberi fasilitas), motivator (pemberi semangat), administrator (sebagai admin) serta evaluator (sebagai pengevaluasi).

Pendidik memiliki peranan penting baik dalam perencanaan dan pengembangan kurikulum. Karena pendidik sebagai perencana dan penegembang kurikulum maka pendidik pula yang mengevaluasi dan menyempurnakan kurikulum baik dari segi pelaksanaan maupun substansi kurikulum itu sendiri. (E. Mulyasa, 2008)

Peran pendidik diatur dalam Undang-undang No. 14 Tahun 2005 tentang Guru dan Dosen menyatakan bahwa:

"Guru sebagai pendidik professional mempunyai tugas utama mendidik, mengajar, membimbing, mengarahkan, melatih, menilai, dan mengevaluasi peserta didik pada pendidikan anak usia dini, pada jalur pendidikan formal,pendidikan dasar, dan pendidikan menengah".

Guru sebagai pendidik dipandang sebagai sebuah profesi diawali dengan pengakuannya pada undang-undang No. 20 tahun 2003 tentang Sistem Pendidikan Nasional yang menetapkan tentang kewajiban yang harus dipenuhi oleh pendidik dan tenaga kependidikan. Amanat itu dijelaskan dalam pasal 40 ayat (2), yaitu pendidik dan tenaga kependidikan berkewajiban:

1) Menciptakan suasana pendidikan yang bermakana, menyenangkan, kreatif, dinamis dan dialogis. 
2) Mempunyai komitmen secara professional untuk meningkatkan mutu pendidikan.

3) Memberikan teladan dan menjaga nama baik lembaga, profesi dan kedudukan sesuai dengan kepercayaan yang diberikan kepadanya.

Berdasarkan rumusan undang-undang dan penjelasan tersebut dapat digambarkan dengan jelas bahwa peran pendidik dalam dunia pendidikan saat ini lebih besar, kompleks, dan strategis untuk membina siswa melalui transformasi nilai-nilai sosial dan budaya dalam pendidikan.

Persatuan, berasal asal kata satu, berarti utuh tidak terpecah-belah, mengandung bersatunya bermacam corak yang beraneka ragam yang bersifat kedaerahan menjadi satu kebulatan secara nasional, juga persatuan segenap unsur Negara Kesatuan Republik Indonesia dalam mewujudkan secara nyata bhineka tunggal ika yang meliputi wilayah, sumberdaya manusia dalam kesatuan yang utuh. Selain itu, persatuan bangsa yang bersifat nasional mendiami seluruh wilayah Indonesia, bersatu menuju kehidupan bangsa yang berbudaya bebas dalam wadah negara RI yang merdeka dan berdaulat, menuju terbentuknya suatu masyarakat madani. ( Pandji Setijo, 2011 )

Adapun butir-butir Pancasila sila ke tiga dapat dilihat sebagai berikut:

1. Mampu menempatkan persatuan, kesatuan, serta kepentingan dan keselamatan bangsa dan negara sebagai kepentingan bersama di atas kepentingan pribadi dan golongan.

2. Sanggup dan rela berkorban untuk kepentingan negara dan bangsa apabila diperlukan.

3. Mengembangkan rasa cinta kepada tanah air dan bangsa

4. Mengembangkan rasa kebanggaan berkebangsaan dan bertanah air Indonesia.

5. Memelihara ketertiban dunia yang berdasarkan kemerdekaan,perdamaian abadi dan keadilan sosial.

6. Mengembangkan persatuan Indonesia atas dasar Bhinneka Tunggal Ika. Memajukan pergaulan demi persatuan dan kesatuan bangsa.

Selanjutnya makna Pancasila Sila Ke-Tiga. Nilai yang terkandung dalam sila Persatuan Indonesia tidak dapat dipisahkan dengan keempat sila lainnya karena seluruh sila merupakan suatu kesatuan yang bersifat sistematis. Sila Persatuan Indonesia didasari dan dijiwai oleh sila Ketuhanan Yang Maha Esa dan Kemanusiaan yang Adil dan Beradab serta mendasari dan dijiwai sila Kerakyatan yang Dipimpin oleh Hikmat Kebijaksanaan dalam Permusyawaratan/Perwakilan dan Keadilan Sosial bagi Seluruh Rakyat Indonesia.

Sila ke -3 ini mempunyai maksud mengutamakan persatuan atau kerukunan bagi seluruh rakyat Indonesia yang mempunyai perbedaan agama, suku, bahasa, dan budaya. Sehingga dapat disatukan melalui sila ini berbeda-beda tetapi tetap satu atau disebut dengan Bhineka Tunggal Ika.

Persatuan Indonesia mengutamakan kepentingan dan keselamatan negara ketimbang kepentingan golongan pribadi atau kelompok seperti partai. Hal yang 
dimaksudkan adalah sangat mencintai tanah air Indonesia dan bangga mengharumkan nama Indonesia. Sila ini menanamkan sifat persatuan untuk menciptakan kerukunan kepada rakyat Indonesia.

Sila yang mempunyai lambang pohon beringin ini bermaksud memelihara ketertiban yang berdasarkan kemerdekaan, perdamaian abadi, dan keadilan sosial bagi seluruh rakyat Indonesia.

Persatuan Indonesia adalah satu untuk Indonesia walaupun keadaan dimasyrakat sangat penuh perbedaan tetapi harus menjadi satu darah Indonesia dan rela mengorbankan kepentingan golongan demi negara Indonesia. Walaupun sangat kental dengan berbagai budaya yang berbeda tetap harus rukun menjaga kedamaian Bhineka Tunggal Ika.

Dalam nilai Persatuan Indonesia terkandung nilai bahwa negara adalah sebagai penjelmaan sifat kodrat manusia monodualis yaitu sebagai makhluk individu dan makhluk social. Negara merupakan suatu persekutuan hidup bersama diantara elemen-elemen yang membentuk negara yang berupa suku, ras, kelompok, golongan, maupun kelompok agama. Oleh karena itu perbedaan adalah merupakan bawaan kodrat manusia dan juga merupakan ciri khas elemen-elemen yang membentuk Negara. Konsekuensinya negara adalah beraneka ragam tetapi satu, mengikatkan diri dalam suatu persatuan yang dilukiskan dalam suatu seloka Bhineka Tunggal Ika. Perbedaan bukannya untuk diruncingkan menjadi konnflik dan permusuhan melainkan diarahkan pada suatu sintesa yang saling menguntungkan yaitu persatuan dalam kehidupan bersama untuk mewujudkan tujuan bersama.

Negara mengatasi segala paham golongan, etnis, suku, ras, individu, maupun golongan agama. Mengatasi dalam arti memberikan wahana atas tercapainya harkat dan martabat seluruh warganya. Negara memberikan kebebasan atas individu, golongan, suku, ras, maupun golongan agama untuk merealisasikan seluruh potensinya dalam kehidupan bersama yang bersifat integral. Oleh karena itu tujuan negara dirumuskan untuk melindungi segenap warganya dan seluruh tumpah darahnya, memajukan kesejahteraan umum (kesejahteraan seluruh warganya) mencerdaskan kehidupan warganya, serta kaitannya dengan pergaulan dengan bangsa-bangsa lain di dunia untuk mewujudkan suatu ketertiban dunia yang berdasarkan perdamaian abadi dan keadilan social.

Nilai persatuan Indonesia didasari dan dijiwai oleh sila Ketuhanan Yang Maha Esa dan Kemanusiaan yang Adil dan Beradab. Hal itu terkandung nilai bahwa bahwa nasionalisme Indonesia adalah nasionalisme religious yaitu nasionalisme yang bermoral Ketuhanan Ynag Maha Esa. Nasionalisme yang humanitik yang menjunjung tinggi harkat dan martabat manusia sebagai makhluk Tuhan. Oleh karena itu nilai-nilai nasionalisme ini harus tercermin dalam 
segala aspek penyelenggaraan Negara termasuk dalam era reformasi dewasa ini. Proses reformasi tanpa mendasarkan pada moral ketuhanan, kemanusiaan, dan memegang teguh persatuan dan kesatuan maka bukan tidak mungkin akan membawa kehancuran bagi bangsa Indonesia.

Nilai persatuan juga dapat berwujud dalam kegiatan gotong royong. Dalam gotong royong tercermin rasa semangat kekeluargaan dan kebersamaan dalam melakukan sesuatu. (Damanhuri, dkk, 2016)

Pancasila sebagai dasar falsafah negara, memberikan pengertian bahwa Persatuan Indonesia adalah persatuan yang berketuhanan Yang Maha Esa, yang berkemanusiaan yang adil dan beradab, yang berkerakyatan yang dipimpin oleh hikmah kebijaksanaan dalam permusyaratan/perwakilan, dan yang berkeadilan sosial bagi seluruh rakyat Indonesia. (Hidayatullah, 2006)

\section{METODE PENELITIAN}

Jenis penelitian ini adalah penelitian deskriptif kualitatif. Metode penelitian kualitatif adalah metode penelitian yang berlandaskan pada filsafat postpositivisme, digunakan untuk meneliti pada kondisi obyek yang alamiah. Pada penelitian kulaitatif lebih menekankan makna dari pada generalisasi. (Sugiyono. 2013). Peneliti mendeskripsikan bagaimana implementasi penanaman nilai sila ketiga Pancasila yang dilakukan atau diperankan oleh pendidik. Data tersebut dapat berasal dari hasil wawancara, observasi, dan dokumentasi.

Penelitian dilaksanakan di SMA Negeri 1 Polewali. Adapun yang menjadi subyek dan atau informan penelitian adalah Pendidik, Pembina, Kepala Sekolah dan Wakil Kepala Sekolah SMA Negeri 1 Polewali, yang dipilih oleh Peneliti secara proporsional sesuai kebutuhan penelitian. Instrumen penelitian yang digunakan adalah, pertama: Pedoman Observasi. Pedoman Observasi digunakan peneliti agar dapat memfokuskan pada data apa yang akan dicari dari kegiatan observasi tersebut. Instrumen Penelitian yang kedua adalah Pedoman Wawancara. Pedoman wawancara dibuat oleh peneliti dengan menyajikan beberapa pertanyaan yang berkaitan dengan fokus masalah yang akan diteliti yaitu mengenai Implementasi Peran Pendidik dalam upaya penanaman sila ke 3 pancasila. Instrumen ketiga yang digunakan adalah pedoman dokumentasi. Pedoman dokumentasi digunakan peneliti untuk memudahkan dokumendokumen apa saja yang harus dicari dan dapat membantu memperjelas data dalam penelitian kualitatif ini. Dokumen yang dicari berupa foto kegiatan, rencana pelaksanaan pembelajaran, profil sekolah dan dokumen lain yang mendukung penelitian. Selanjutnya analisa data dilakukan dengan cara reduksi data, penyajian data, dan penarikan kesimpulan (Gunawan, 2013). 


\section{HASIL DAN PEMBAHASAN}

Berikut diuraikan hasil pelaksanaan penelitian berupa hasil wawancara, hasil observasi, hasil pengumpulan dokumen terkait, temuan penelitian, hasil analisis dan capaian luaran.

Berdasarkan hasil wawancara dengan kepala sekolah Drs. Muhammad Faezal, M.Si bahwa secara umum penanaman Pancasila telah ada dalam Pembelajaran. Kemudian penanaman nilai pancasila juga diterjemahkan dalam pengembangan karakter. Ada 18 Karakter yang diharapkan dan di kembangkan di sekolah. Terkait 18 karakter yang ditanamkan, dikerucutkan dan dikembangkan menjadi lima karakter besar yaitu Nasionalisme, Gotong Royong, Mandiri, Religius, dan Cinta Tanah Air. Jadi semua kegiatan di sekolah itu mengarah ke pengembangan karakter yang sesuai dengan nilai Pancasila. Penilaiannya kepada peserta didik itu menggunakan pengamatan langsung oleh guru. Setiap minggu guru melaporkan perkembangan atau prilaku peserta didik kaitan dengan pengembangan karakter yang sesuai dengan nilai Pancasila. Kepada peserta didik yang dianggap punya masalah dibina dengan melibatkan guru-guru lain seperti wali kelas, guru pembina lembaga kesiswaan sekolah, dan guru BK.

Penanaman nilai pancasila khususnya sila ketiga dilakukan oleh guru kepada peserta didik melalui kegiatan pengelolaan dan penataan kelas misalnya tentang kebersihan dan keindahan kelas. Kegiatan penanaman nilai pancasila berikutnya adalah melalui gotong royong jumat bersih, dan kegiatan bersamasama mencintai lingkungan. Mencintai, menjaga lingkungan juga bagian dari kecintaan pada tanah air. Penanaman kecintaan tanah air lainnya melalui kegiatan ekstrakurikuler misalnya Pramuka, Smansa Green School (SGS). Kelompok SGS melakukan kegiatan cinta lingkungan didalam sekolah dan luar sekolah. Kegiatan luar sekolah dilakukan melalui pembersihan pantai dan penanaman mangrove. Jadi setiap hari lingkungan hidup SGS melakukan kegiatan-kegiatan cinta dan peduli lingkungan.

Penanaman nilai pancasila kaitan cinta tanah air dilakukan melalui pembentukan Study Club LCC. Kelompok ini menjadi ajang diskusi dan belajar bagi peserta didik untuk pemahaman nilai kebangsaan, cinta tanah air dan nsionalisme, termasuk juga untuk mengikuti lomba-lomba. Terkait kecintaan kepada tanah air setiap hari senin pada upacara bendera, pihak kepolisian (Polres Polman) dan TNI (Dandim) datang memberi penanaman cinta tanah air dan negara kesatuan republik indonesia.

Lebih lanjut diuraikan hasil wawancara dengan wakil kepala sekolah bidang kurikulum yang juga sebagai guru (Drs. Abdul Rasyid) bahwa Penanaman nilai Pancasila sila ketiga melalui lembaga ekstrakurikuler sebanyak ada tiga puluh lembaga yang ada yang mempunyai dampak penanaman Pancasila. 
Bentuk penanaman lainnya seperti pembentukan kepanitiaan kegiatan keagamaan. Panitianya melibatkan peserta didik dari lintas agama. Dalam kepanitiaan hari besar Islam seperti Maulid, dilibatkan sebagai Panitia juga dari peserta didik yang beragama Nasrani. Mereka berpartisipasi menyatu saling membantu menyukseskan kegiatan tersebut.

Dalam penerimaan peserta didik baru, sekolah juga tidak melihat persoalan SARA atau perbedaan suku dan agama, semua terakomodir melalui seleksi yang dilakukan oleh sekolah.

Kecintaan kepada tanah air dan kebangsaan juga diwujudkan melalui lomba-lomba memperingati hari-hari Nasional, hari sumpah pemuda, hari pahlawan, dan hari kemerdekaan. Lomba-lomba yang diselenggarakan oleh peserta didik melalui kolaborasi beberapa lembaga kelompok ekstrakurikuler melaksanakan lomba menulis, lomba cerdas cermat, mengangkat sosok-sosok pahlawan, mengekspresikan tentang perjuangan tokoh-tokoh pahlawan kemerdekaan. Dengan begitu peserta didik mengetahui siapa dan bagaimana peran dan perjuangan tokoh-tokoh pahlawan nasional dan lokal. Selanjutnya dalam kegiatan tersebut bertujuan untuk mempelajari bagaimana mengaplikasikan nilai perjuangan para pahlawan pada masa sekarang ini.

Penanaman nilai-nilai Pancasila juga dilakukan melalui ekstrakurikuler pramuka. Pada SMA 1 Polewali ada yang disebut dengan pramuka wajib, semua peserta didik diperkenalkan pramuka dan dasar-dasar pramuka. Lebih lanjut untuk bakat dan minat, lebih mendalam dan luas ketika menjadi anggota dan pengurus pramuka sekolah.

Penanaman nilai Pancasila khususnya sila ketiga juga melalui kegiatan yang diselenggarakan oleh pihak lembaga luar sekolah seperti Badan Kesbangpol melalui kegiatan Wasbang (Wawasan Kebangsaan), peserta didik diundang mendengarkan ceramah penanaman wawasan kebangsaan dan mengikuti beberapa lomba-lomba yang diselenggarakan.

Dalam kurikulum di SMA 1 Polewali semua mata pelajaran terintegrasi dalam hal penanaman karakter, yang tentunya diantaranya tentang karakter tentang kecintaan pada tanah air dan nasionalisme. Hal ini untuk meningkatkan hasil belajar pada tiga ranah yaitu kognitif, psikomotorik dan afektif. Terus terkait dengan mata pelajaran Pancasila yang digabung dengan kewarganegaraan sebenarnya tidak ada yang hilang. Hanya pengetahuan atau materi tentang Pancasila yang sedikit dari sebelumnya. Tapi dari segi aplikasi nilai-nilai, justru melalui kurikulum sekarang semua terintegrasi dalam setiap mata pelajaran melalui penanaman karakter. Tentang materi pembelajaran atau bahan ajar guru diharap kreatif dan inovatif untuk mengembangkan materi dan bahan ajar melalui pendekatan lokalitas misalnya mencontohkan pahlawan-pahlawan lokal, dengan tetap mengacu pada silabus pembelajaran. 
Selanjutnya tentang faktor berpengaruh terhadap pemahaman dan pengamalan Pancasila itu dipengaruhi oleh faktor keluarga yang ikut membentuk kepribadian anak dari awal (citra diri dan keluarga). Lalu faktor lembaga/institusi, yaitu nama baik sekolah atau citra sekolah sebagai salahsatu sekolah pilihan, sehingga memotivasi peserta didik untuk menjaga nama baik sekolah sehingga senantiasa berprilaku sesuai dengan nilai pancasila dan senantiasa berprestasi. Faktor berpengaruh berikutnya adalah soal materi pembelajaran yang terus dikembangkan dan bersesuaian dengan nasionalisme dan persatuan. Adapun kendala-kendala dalam penanaman nilai pancasila yang dihadapi oleh pihak sekolah, lebih kepada tantangan. Sekarang ini terkait arus globalisasi dengan pemakain teknologi IT melalui misalnya hp andorid, menjadi tantangan karena kalau tidak digunakan juga akan ketinggalan. Akan tetapi dengan pemakaian alat teknologi tersebut juga tidak bisa kebablasan. Harus diawasi dari paham-paham dari luar, kebebasan. Tetap melakukan pemantauan kepada aktivitas dan perkembangan peserta didik pada kegiatan organisasi atau lembaga Rohis (Rohani Islam) dari paham-paham esktrim, dengan cara melihat penceramahnya misalnya. Dilakukan dengan konsep pembinaan dan tetap memantau aktivitas ekstrakurikuler peserta didik. Pengelola SMA 1 Polewali tetap berupaya terus mengetahui dan memantau aktivitas peserta didik. Tantangan berikutnya adalah soal lingkungan, lingkungan luar sekolah yang mempengaruhi peserta didik.

Selanjutnya berdasarkan hasil wawancara yang didukung dengan observasi peneliti, diuraikan oleh guru mata pelajaran PPKn SMA 1 Polewali yang juga sebagai ketua Musyawarah Guru Mata Pelajaran (MGMP) PPKn kabupaten Polewali Mandar bapak Drs. Hermansyah. L, bahwa implementasi nilai pancasila pada sekolah hampir sama semua sekolah cuma dalam bentuk kegiatan mungkin ada yang spesifik. Implementasi nilai persatuan di sma 1 polewali dalam bentuk kegiatan jumat bersih setiap minggu. Semua peserta didik terlibat dan bertanggungjawab dalam membersihkan kelasnya, dan menata taman depan kelas. Kemudian ada beberapa kegiatan organisasi dibawah naungan Osis seperti Balasewa, Green House dan lain-lain. Peserta didik melalui Green House ini mengumpulkan sampah-sampah plastik untuk di daur ulang. Dalam kegiatan tersebut terdapat nilai kebersamaan. Hal ini sebetulnya dilakukan sebagai upaya pembiasaan bagi peserta didik.

Penanaman nilai sila ketiga Pancasila juga dilakukan melalui kerja-kerja kelompok. Pemberian aktivitas berkelompok, dalam kegiatan tersebut peserta didik mengerajakan secara bertanggungjawab dan bersatu. Kegiatan tersebut misalnya dalam kegiatan kewirausahaan. Peserta didik membuat makananmakanan tradisional khas daerah secara berkelompok dan bersama-sama. Peserta didik memamerkan produknya lalu guru membeli produk-produk peserta didik. Mereka bangga dengan produknya sebagai karya asli Indonesia. Kegiatan- 
kegiatan ini disebut di SMA 1 Polewali sebagai Prakarya yang rutin dilakukan setiap akhir semester.

Selanjutnya penanaman cinta tanah air dilakukan dengan diadakan lomba pada setiap perayaan kemerdekaan 17 agustus, seperti lomba pidato, drama teatrikal, sebagai bagian dari penanaman cinta tanah air. Mengikuti lomba olimpiade PPKn yang diselenggarakan oleh Perguruan Tinggi, dan tahun 2019 juara 1 lomba debat di Makassar. Kemudian mengikuti lomba dalam hal Sosialisasi Undang-Undang 1945, lomba 4 pilar kebangsaan. Dalam lomba 4 pilar kebangsaan ini berhasil meraih juara tiga tingkat nasional. Pada tahun 2020 menargetkan juara 1 nasional Cuma karena masa pendemi covid19 sehingga kegiatan ini tidak dilakukan.

Juga ada hal yang paling menarik telah dilakukan dalam soal kecintaan kepada tanah air melalui kegiatan pramuka. Program kepramukaan ini ada dua yaitu program Pramuka wajib dan program pramuka ekstrakurikuler sesuai pengembangan minat dan bakat. Program pramuka wajib itu dilakukan bagi peserta didik kelas $\mathrm{X}$ dengan istilah di sekolah adalah program pramuka blok. Dalam kegiatan ini sangat tinggi muatan penanaman nilai patriotisme dan cinta tanah air. Semua peserta didik wajib mengikuti program 'pramuka wajib'.

Kemudian kegiatan berikutnya yaitu ekstrakulikluer Balasewa sebagai implementasi cinta tanah air yang diwujudkan dalam kegiatan cinta lingkungan. Kegiatannya dalam bentuk penanaman pohon mangrove di pantai Mampie dan pelepasan tukik-tukik (anak penyu) supaya bisa berkembang biak. Selanjutnya peserta didik juga berpartisipasi dalam bersih-bersih pantai Bahari Polewali. Kegiatan ini dalam bentuk partisipasi bersama pemerintah daerah dalam hal mencintai lingkungan, tentu ini bagian dari pada kecintaan pada tanah air. Peserta didik juga terlibat berpartisipasi dalam kegiatan bersih-bersih pasar sentral. Kegiatan-kegiatan ini senantiasa dilakukan dan dikembangkan. Tanpa kegiatan ini peserta didik akan menjadi generasi yang individualis. Apalagi dengan era sekarang ini pengaruh media sosial dan tekhnologi sangat besar mempengaruhi anak atau peserta didik, misalnya game-game online. Oleh karena ini peserta didik selalu dilibatkan dalam kegiatan cinta tanah air melalui kegiatan-kegiatan cinta lingkungan, baik yang dilakukan oleh pemerintah, masyarakat, maupun oleh sekolah melalui program kegiatan Osis.

Terkait dengan konten materi pembelajaran yang sekarang, nama mata pelajarannya adalah Pendidikan Pancasila dan Kewarganegaraan. Berbeda misalnya sebelumnya pernah disebut dengan mata pelajaran pendidikan moral Pancasila. Jadi sekarang materi nilai-nilai Pancasila berkurang bahkan hilang, terjadi perubahan yang signifikan. Padahal sebenarnya dengan materi pancasila yang luas dan dalam diharapakn dapat meredam gejolak-gejolak disintegrasi bangsa, toleransi, dan radikalisme. Sekarang yang ada hanya materi-materi umum 
terkait kewarganegaraan, misalnya teori-teori politik. Jadi memang berbeda dengan tahun-tahun sebelumnya dengan istilah garis-garis pelaksanaan pembelajaran (GBPP), didalamnya ada tambahan suplemen materi nilai-nilai Pancasila. Pada saat itu dalam materi pembelajarannya dimulai dari sila pertama misalnya soal ketakwaan, sila kedua soal kemanusiaan, sila ketiga soal persatuan, sila keempat musyawarah, sila kelima soal keadilan sosial. Hal itu yang dibahas lalu diimplementasikan. Tapi setelah terjadi perubahan kurikulum KBK 2004, maka berubahlah menjadi pendidikan pancasila dan kewarganegaraan. Meskipun terdapat pancasila tapi tidak terlalu luas dan dalam konten materinya. Pada saat itu Kurikulum Berbasis Kompetensi (KBK) 2004 banyak perubahan materi PPKn. Kemudian berubah menjadi kurikulum 2013 (Kurtilas), dan terus berubah hampir setiap tahun materi PPKn berubah. Terakhir ada lagi buku revisi materinya berubah lagi terutama kelas 3 (kelas XII). Dulu ada 7 materi/sub materi sekarang menjadi 4 materi.

Sebagai guru hanya mengikuti saja apa yang ditetapkan dari pemerintah, guru hanya sisa mengkondisikan dan kreatif, mengembangkan dan menyesuaikan dengan situasi yang ada. Bahkan terakhir dengan masa covid19 ini materi PPKn sangat disederhanakan, dimana semua kompetensi dasar yang ada didalam tidak wajib diberikan semua kepada peserta didik, hanya dipilih-pilih yang esensial. Esensial maksudnya ada nilai kritisnya dan ada nilai kreativitasnya. Jadi akhirnya pendidikan pancasila terkait penanaman materi dianalisa mana yang sesuai dengan kebutuhan dengan perkembangan demokrasi dan politik di Indonesia. Karena mata pelajaran Pancasila otomatis selalu berbicara masalah politik. Nah hal paling dituntut oleh peserta didik dari pembelajaran politik adalah praktisnya, bukan teoritisnya. Karena dengan hanya teori peserta didik bosan, sementara peserta didik kritis mengatakan bahwa faktanya politik seperti ini. Jadi sebagai guru PPKn tidak boleh menutup ruang kepada peserta didik untuk menyampaikan pendapat, tapi tidak boleh juga mengikuti pendapat peserta didik yang keliru. Jadi kedepan ketika peserta didik berdemokrasi mereka sudah memiliki pemahaman konsep yang telah ditanamkan guru untuk tidak melakukan misalnya politik uang.

Terkait hal pengaruh dalam hal penanaman dan pengamalan pancasila pada peserta didik. Kendala yang dihadapi oleh guru adalah soal waktu materi pelajaran yang hanya dua jam sementara guru banyak dituntut hal penanaman kedalaman keluasan materi. Belum lagi banyaknya mata pelajaran yang ada disekolah. Namun terkait apakah ada pengaruhnya dari pemberian materi PPKn kepada peserta didik, tetap ada dalam praktek misalnya nilai gotong royong, persatuan, kemanausiaan, dan lain-lain. Hal itu bisa lebih tajam diperaktekkan diterapkan dalam dan luar kelas. Dalam masa pendemi covid19 tatap muka juga tidak bisa dihilangkan karena ada roh dalam pembelajaran ketika guru dan 
peserta didik bertemu, misalnya soal pskilogisnya dan emosionalnya. Hal ini tidak bisa digantikan dengan teknologi apapun. Namun supaya tidak terjadi kebosanan peserta didik dan bagian dari variasi pembelajaran maka teknologi tetap bagus untuk digunakan. Lebih lanjut faktor berpengaruh dalam penanaman dan pengamalan nilai pancasila pada peserta didik, bukan hanya dari segi mata pelajaran PPKn, tapi juga guru, orang tua, dan masyarakat. Perlu ada kerjasama antara pihak dalam memaksimalkan penanaman pemahaman dan pengamalan pancasila bagi peserta didik. Misalnya guru sudah menerapkan bagaimana musyawarah dalam kelas, itu harus didukung oleh orang tua ketika menyelesaikan masalah dalam rumah tangga, dengan melibatkan semua anggota keluarga untuk membicarakan dan menyelesaikan masalah.

Jadi sebenarnya penanaman pemahaman cinta tanah air untuk masa sekarang bagi peserta didik bukan lagi misalnya seperti dulu berjuang misalnya melawan Belanda, itu sangat sempit. Jadi untuk penanaman patriotisme dan nasionalisme untuk peserta didik ada dua yang ditanamkan yaitu bahwa mereka menyadari diri sebagai warga negara yang mesti taat hukum, diluar sana ada aturan yang mesti ditaati. Terus untuk penanaman patriotisme itu dilakukan dengan bahwa peserta didik mesti mempunyai kepedulian, seperti kepedulian terhadap lingkungan. Jadi ditanamkan kesadaran, dan kesadaran itu mulai ditanamkan dalam lingkungan sekolah, misalnya terkait sampah. Pembelajaran tidak dilakukan kalau masih ada sampah dalam kelas. Pekerjaan sebagai guru PPKn memang pekerjaan yang berat. Walaupun di sekolah sudah ditanamkan nasionalisme, patriotisme dan penanaman lainnya yang sedemikian rupa. Tapi kalau tidak dilanjutkan dengan peran elemen luar sekolah maka juga tidak akan maksimal. Maka diperlukan peranan orang tua dan masyarakat.

Kendala-kendala yang dihadapi dalam penanaman nilai pancasila adalah media-media seperti tayangan-tayangan televisi seperti sinetron banyak yang jauh dari nilai-nilai Pancasila. Kendala berikutnya adalah tekhnologi dan media sosial, misalnya permainan game-game online yang banyak dampak negatif bagi peserta didik. Tapi sebagai guru tetap mesti selalu optimis menghadapi kendala-kendala yang ada. Guru tidak boleh berhenti memberikan nasehat, arahan dan didikan kepada peserta didik.

Senada dengan apa yang disampaikan oleh sumber atau informan sebelumnya, seorang guru PPKn Hj. Siti Aras, S.Pd, M.Pd menguraikan bahwa penanaman nilai pancasila sila ketiga dilakukan dengan melibatkan peserta didik berpartisipasi dalam upacara hari besar kebangsaan yang dilaksanakan oleh pemerintah daerah. Dapat dicontohkan partisipasi peserta didik pada peringatan hari sumpah pemuda yang dilaksanakan oleh Pemda dengan cara memakai pakaian adat. Penanaman nilai juga dilakukan dengan berpartisipasi dalam upacara 17 agusutus hari kemerdekaan. 
Implementasi penanaman nilai pancasila khususnya sila ketiga kepada peserta didik melalui pembentukan sikap menempatkan persatuan dan atau kepentingan umum diatas kepentingan pribadi. Dalam proses pembelajaran PPKn termasuk mata pelajaran yang lain juga dilakukan penilaian sikap yang dilakukan oleh guru untuk memastikan apakah sikap peserta didik bersesuaian dengan penanaman nilai pancasila dan karakter kebangsaan.

Bentuk implementasi penanaman nilai pancasila juga dilakukan dengan mengajak peserta didik pada Hari Pendidikan Nasional untuk mengunjungi guru yang sudah pensiun, untuk mengingat jasa-jasa guru.

Terus implementasi penanaman nilai berikutnya melalui penataan dikelas. Masing-masing didepan kelas terpasang bendera merah putih, lambang burung garuda Pancasila, gambar atau foto pahlawan nasional dan lokal. Menariknya karena penataan kelas ini dilombakan antar tiap kelas, dan sertifikat lomba dipajang dalam kelas untuk menjadi motivasi peserta didik untuk tetap memperbaiki penataan dan menjaga ruang kelas agar tetap tampil menarik dan nasionalis. Pada masa pendemi covid19 sikap dan nilai persatuan, kerjasama, terus ditanamkan kepada peserta didik.

Hambatan dan atau tantangan yang dihadapi pendidik dalam penanaman nilai pancasila adalah perbedaan sudut pandang dan perbedaan karakter peserta didik. Juga dengan adanya internet dan media sosial yang membawa dampak positif dan negatif. Positifnya adalah peserta didik mudah mengakses materi pembelajaran dan undang-undang. Tapi negatifnya juga dengan mudah mengakses konten-konten negatif yang tidak boleh diakses oleh peserta didik. Pada masa pendemi covid19 para orang tua juga sangat diharapkan untuk berperan ikut serta mendidik dan membina anak.

Untuk lebih memperkuat hasil penelitian, peneliti juga melakukan wawancara dengan guru mata pelajaran selain guru PPKn yaitu Guru Fisika (Wahdina, S.Pd, M.Pd) menyampaikan bahwa penanaman nilai pancasila utamanya nilai sila ketiga juga dilakukan oleh guru-guru selain guru PPKn. Penanaman nilai pancasila dilakukan pada saat memulai dan mengakhiri proses pembelajaran. Bentuknya dengan memberi nasehat kepada peserta didik untuk tetap melaksanakan gotong royong, saling membantu dalam keluarga. Hal lain yang dilakukan oleh semua guru kepada peserta didik pada masa pendemi covid19 adalah pada saat proklamasi perayaan 17 agustus, guru-guru meminta kepada semua peserta didik melakukan 'sikap sempurna' berdiri selama 3 menit. Selanjutnya peserta didik diminta untuk mengirimkan foto dan video tentang hal tersebut kepada guru. Hal tersebut dilakukan karena hasil belajar mesti selalu mencapai tiga ranah yaitu kognitif, psikomotorik, dan afektif.

Selanjutnya peneliti juga menguraikan hasil wawancara dengan Guru Bimbingan Konseling yang juga sebagai Pembina Ekstrakurikuler Kelompok 
Adiwiyata (Sahriani, S.Pd, M.Pd). Penanaman nilai pancasila oleh guru bimbingan konseling dilakukan dalam bentuk layanan dan konseling. Dalam pemberian layanan-layanan individual, konseling kelompok dan bimbingan kelompok, dimasukkan tentang nilai Pancasila terutama nilai sila ketiga pancasila seperti rasa bangga menjadi bangsa Indonesia.

Penanaman nilai Pancasila dilaksanakan melalui ekskul Paskibraka. Selain itu implementasi nilai Pancasila terkait cinta tanah air melalui kecintaan terhadap lingkungan. SMA 1 Polewali menjadi sekolah pertama yang mendapatkan predikat sebagai sekolah Adiwiyata Mandiri tahun 2018. Dalam pelaksanaan cinta lingkungan oleh warga sekolah peserta didik, guru dan tenaga pendidikan, itu dilakukan secara gotong royong dalam melaksanakan jumat bersih, peserta didik merawat tanaman, dan banyak kegiatan yang terkait dengan cinta lingkungan. Termasuk kegiatan-kegiatan yang dilaksanakan dalam rangka Hari Ozon dan Hari Lingkungan Hidup, peringatan Hari Bumi, Hari Air.

Memotivasi untuk terus berprestasi dengan ikut kegitan lomba tingkat provinsi dan nasional mengharumkan nama sekolah. Penanaman untuk mencintai produk lokal itu dilakukan dalam kegiatan masa orientasi sekolah (MOS) melalui penggunaan tas dari hasil sampah daur ulang. Kegiatan lain adalah melalui prakarya kewirausahaan menampilkan produk lokal dalam hal kuliner. Termasuk juga menampilkan karya produk daur ulang oleh kerajinan tangan peserta didik yang berbahan dari bahan batok kelapa.

\section{SIMPULAN}

Memperhatikan uraian dan pembahasan hasil wawancara, observasi, dokumen terkait disimpulkan bahwa implementasi penanaman nilai sila ketiga pancasila pada peserta didik dilaksanakan melalui lembaga/sekolah dan peran pendidik/guru dalam proses pembelajaran dikelas, melalui; (1) penanaman materi, (2) kegiatan ektrakurikuler, (3) kegiatan kerjasama dengan mitra pemerintah daerah, serta (4) peran serta masyarakat dan orangtua. Disarankan agar pengelola sekolah dan pendidik/guru terus melakukan inovasi, kreativitas dan kerjasama dengan beberapa stakehoulder dalam menanamkan nilai-nilai Pancasila kepada peserta didik.

\section{DAFTAR PUSTAKA}

Asmani A. J. (2011). Tips Menjadi guru Inspiratif, kreatif, dan Inovatif. Yogyakarta: Diva Pres.

Damanhuri, D., Bahrudin, F. A., Legiani, W. H., \& Rahman, I. N. (2016). Implementasi Nilai-Nilai Pancasila Sebagai Upaya Pembangunan Karakter Bangsa. Untirta Civic Education Journal, 1(2). 
Hidayatullah, S. (2006). Notonagoro dan Religiusitas Pancasila. Jurnal Filsafat, $16(1), 34-41$.

Imam, G. (2013). Metode Penelitian Kualitatif Teori dan Praktik. Jakarta: Bumi Aksara.

Mulyasa, E. (2008). Menjadi Guru Profesional Menciptakan Pembelajaran, Bandung: Remaja Rosdakarya.

Pratiwi, N. R. (2018). Strategi Penanaman Nilai-Nilai Pancasila Di Sekolah Menengah Kejuruan. E-CIVICS, 7(6), 649-656.

Pusat Kurikulum dan Pembelajaran Kemdikbud, (2019). Penguatan dan Pembelajaran Nilai Moral Pancasila. Jakarta.

Setijo, P. (2006). Pendidikan Pancasila Perspektif Sejarah Perjuangan Bangsa: Dilengkapi dengan Undang-Undang Dasar 1945 Hasil Amandemen. Grasindo.

Soeprapto, S. (2017). Aktualisasi Konsep Filsafat Pancasila Notonagoro sebagai Dasar Pengembangan Ilmu Pengetahuan. Menara Ilmu Pancasila, Kanal Pengetahuan Filsafat

UGM. https://pancasila.filsafat.ugm.ac.id/2017/09/19/aktualisasi-konsep-filsafatpancasila-notonagoro-sebagai-dasar-pengembangan-ilmu-pengetahuan/ Diakses tanggal 10 Agustus 2019.

Sugiyono. 2013. Metode Penelitian Pendidikan Pendekatan Kuantitatif, Kualitatif, dan R\&D. Bandung: Alfasbeta.

Undang-Undang Nomor 14 Tahun 2005 tentang Guru dan Dosen. LembaranNegara Republik Indonesia Tahun 2005 Nomor 157. 